\title{
JOURNEY FROM IOWA FARM BOY TO ANIMAL RIGHTS BIBLIOGRAPHER
}

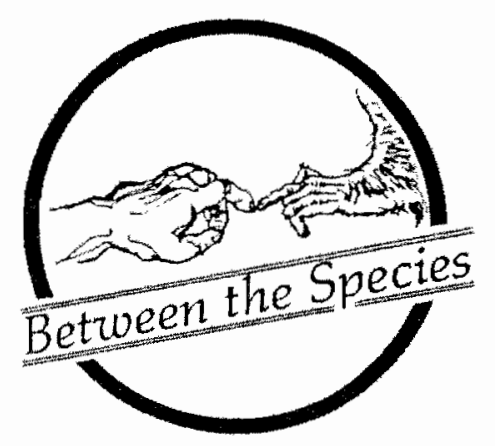

\section{Charles Magel}

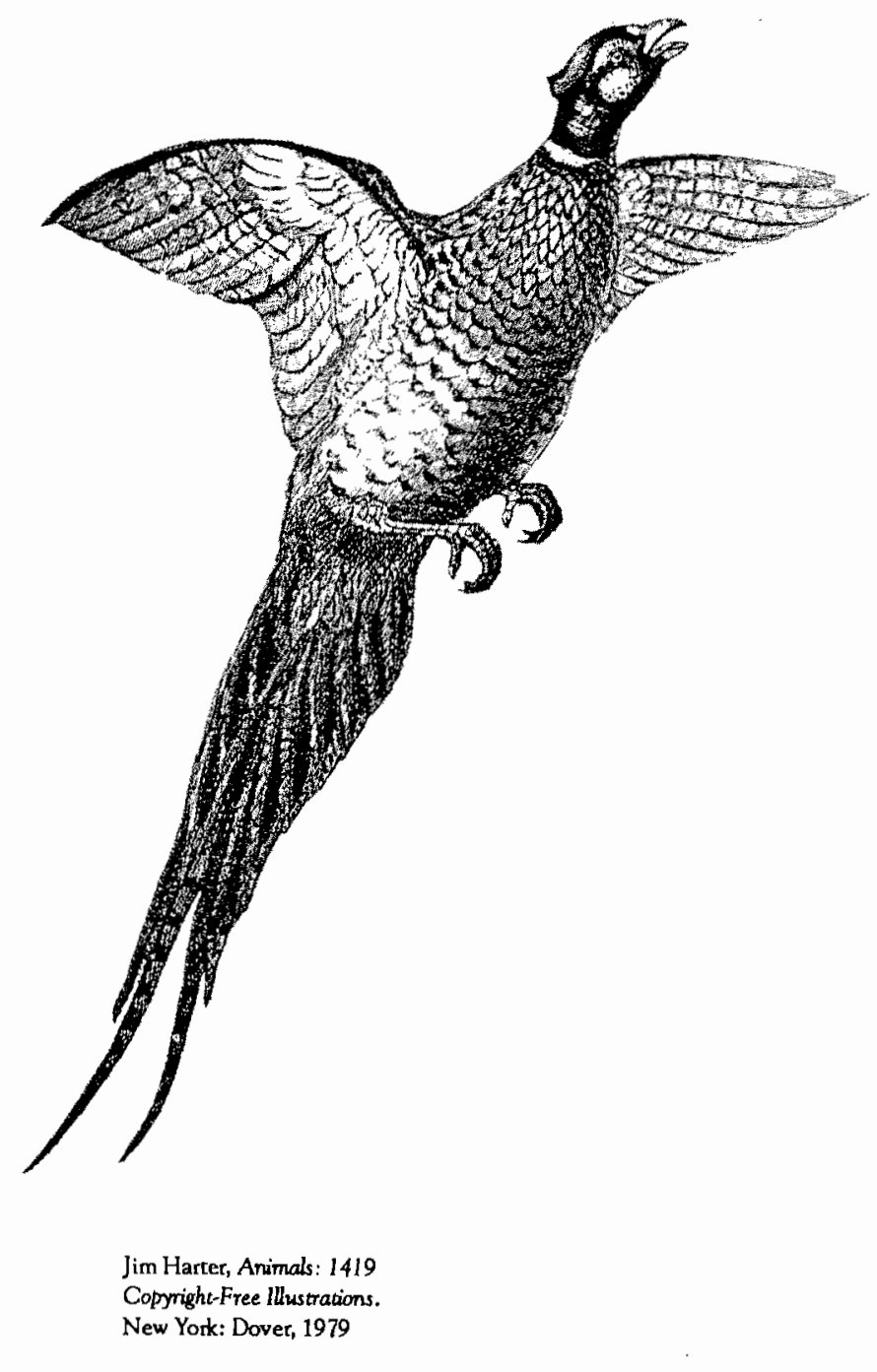

In 1920 I became the final installment of a family of eight. We lived on a marginal 150 -acre farm eight miles west of Burlington, Iowa. So marginal, I could detect no difference when the Great Depression hit.

Animals were taken for granted. Pigs were sufficiently numerous to constitute a pig farm. Cows, horses, chickens and ducks completed the farmanimal community. Although I cannot remember what canine breed Ring was supposed to be, he was a faithful friend to all. My oldest brother always kept red squirrels in a huge outdoor wire cage. Jim, a tame crow, was a constant source of amusement: his attempts to imitate human sounds were hilarious; his snatching and hiding washers and bolts and nuts and tiny engine parts from my brother's auto repair shop generated panic; he accompanied my father on the mile walk to the mail box, perched on his shoulder or flitting ahead from telephone pole to telephone

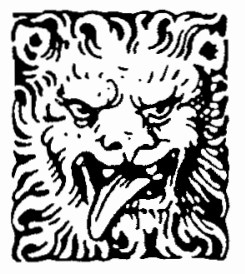

\section{AUTO- BIOGRAPHY}


pole; his unlimited hostility to our neighbor Jim Walker was so intense that Mr. Walker enjoyed the experience of letting him draw blood on the back of his hand. Anyone who has lived with a crow will not be surprised at the recent discovery by cognitive psychologists that birds (pigeons) have concepts.

Silvermane was an unbelievably fast and spirited pony; but his mean trick of suddenly halting after attaining full speed, tumbling rider over his head, and then racing home solo, generated my distrust of horses. Dossy, the work horse, was equally undependable for riding; leaving home, she stubbornly maintained a walk barely distinguishable from standing still; returning home, she leaped into an uncontrollable gallop. My mother's favorite transportation was horse and buggy; my trips with her are the source of fond memories. Not so pleasant are memories of trying to remain upright on a dusty harrow behind sweaty horses. It was more fun to be the horse-drawn water boy at threshing time.

Carol Belanger Grafton, Old-Fashioned Animal Cuts. New York: Dover, 1987

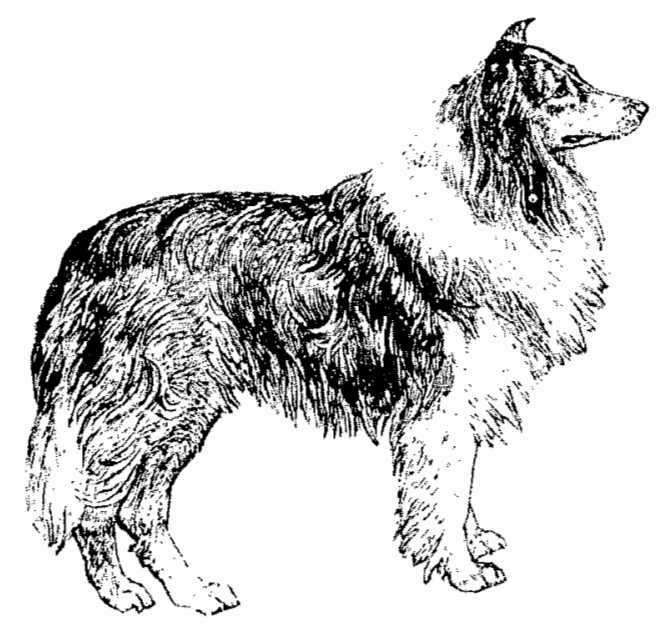

Hog butchering in late fall or early winter originated excitement. I do not know how the adults viewed it, but for a ten year old there was a tinge of festivity. Huge outdoor hickory fires under cauldrons of boiling water. I have no vivid image of the slaughter; perhaps it was too traumatic for retention in memory; it must have been by rifle shot or slitting of throat. Rendering lard in cast iron kettles over open fire was followed by pressing down the cracklings - crusty, golden-brown, grease-filled chunks which smelled much better than they tasted, but were always sampled. The process of emptying and scraping intestines was too messy and foul to watch; but several days later, at sausage-stuffing time, the origin of the casings was forgotten. The final process took place in the smoke house where hams and shoulders hung for months in the blackening fumes of smoldering hickory.

I occasionally hunted squirrels and rabbits, set traps for mink, and fished. But in none of these activities was I proficient, and from none of them did I experience much satisfaction.

My first eight years of education were in a oneroom country school. During high school, animals continued to play a role. Living with my cousin who operated a small Jersey dairy farm, I fell into a daily routine: milking, washing bottles, filling bottles, and delivering to thirty homes. It was at this time that Scooter entered my life. For some reason unknown to me a family from town brought to the dairy farm the ugliest and oddest dog I had ever seen - a fouryear-old black and tan Dachshund. It took a year for Scooter and me to know each other and for me to begin to appreciate her beauty. I was amazed at the consistency of her personality and the intensity of her emotions. We lived together four years; I will never forget her, and she never forgot me, even after years of absence.

My best high school friend decided to study agricultural science at lowa State College. I decided to go too, but chose electrical engineering. We had much in common, except for finances: his affluent father owned the International Harvester farm machinery agency; my assets totaled sixty-five dollars. Two weeks before Thanksgiving three dollars remained. Raisin bread and milk provided survival until Thanksgiving vacation. 
Robert E. Pettigrew, owner of four hotels and two auto dealerships, was generally known to be the wealthiest person in Burlington. The day after Thanksgiving I entered his office, introduced myself, and informed him I would have to drop out of school unless I received financial assistance. He suggested I return in four days, at which time he took me to the men's store, bought a heavy winter coat, handed me a $\$ 150$ check and told me to let him know when I needed more. My financial problems were over.

Following my freshman year I became a night clerk at one of Mr. Pettigrew's hotels. One evening he asked "What do you want to do when you finish college?" "I think I would like to teach." "But there is no money in teaching!" That one sentence erased from my mind the possibility of teaching.

Animals played no significant role in my life during three years at Northwestern University, nor during five years as paymaster and contract termination officer in the Naval Reserve during World War II. But by the end of the war it became evident that I had become a member of the Pettigrew family and that I would become manager of the Pettigrew hotels. Before returning to Burlington I spent three months at a chefs' and meat cutting school in Minneapolis.

By 1950 I had a national reputation in hotel management, was sufficiently affluent to join a private hunting club, and regularly wrote feature articles for Hotel Monthly magazine. One of those articles reported my calculation of the ratio between the cost of raw meat and the cost of cooked meat. For example: to determine the cost per cooked pound of turkey meat ready to serve multiply the raw cost per pound (fully dressed) by 3.0 . There were similar calculations for various cuts of chicken, veal, lamb, pork and beef.

During my thirtieth year I heard a Presbyterian minister mention the name "Albert Schweitzer." The next day I went to the library, checked out Schweitzer's Out of My Life and Thought, took it to Crapo Park, and read it in one sitting. That was my first exposure to the phrase "reverence for life." Within two weeks I decided to resign the hotel position and enter graduate school in philosophy.
I drove to Minneapolis, found the Philosophy Department at the University of Minnesota, and requested admission. "Where did you do your undergraduate work in philosophy?" "I have had no philosophy." "Why do you want to enter graduate school in philosophy?" "Because I read Albert Schweitzer's autobiography." I am eternally grateful to the University of Minnesota for letting me in.

Instead of Albert Schweitzer and reverence for life, I found myself studying A.J. Ayer and logical positivism, G.E. Moore and analytic philosophy, Ludwig Wittgenstein and linguistic philosophy, Søren Kierkegaard and existentialism. During twelve years as student and instructor at the University of Minnesota I heard nothing about Schweitzer and nothing about animals.

In 1962 I accepted an appointment to initiate a philosophy program at Moorhead State University, Moorhead, Minnesota - a project which resulted in twenty-four years of enjoyable teaching.

Two 1975 publications profoundly influenced my thought and life: Tom Regan's "The Moral Basis of Vegetarianism" and Peter Singer's Animal Liberation. I became a vegetarian, switched to a life style consistent with animal liberation, and introduced an animal rights course into the philosophy curriculum. This may have been the first course totally on animal rights to be offered regularly at the university level.

Helen Jones, President of International Society for Animal Rights, deserves heavy credit for my 1981 Bibliography on Animal Rights and Related Matters. It was her idea; she negotiated the contract with University Press of America; and her staff prepared the typescript.

In 1985 I retired from teaching. Three days before my departure for San Diego a letter arrived from Mansell Publishing Limited, London: "Would you like to prepare a Keyguide to Information Sources in Animal Rights?"

The Keyguide will have four parts. Part $I$ is an overview of the animal rights literature, in six chapters: Philosophy and animals, Science and 
medicine and animals, Education and animals, Law and animals, Religion and animals, Vegetarianism and animals. Part II is an annotated bibliography of 335 works in defense of, or tending toward, or consistent with, or historically important for animal rights. Part III lists 182 organizations (international and regional, and national) - not only those which adopt a strong animal rights position but those which from various perspectives are concerned with animal welfare. Part IV lists over 950 works referred to in Part $\mathrm{I}$.

\section{The expression "animal rights" is fundamentally an ethical concept; consequently the issue of animal rights is essentially a philosophical issue.}

The animal rights movement began in the early 1970s. As early as 1964 Ruth Harrison's Animal Machines: The New Factory Farming Industry had aroused public indignation in Great Britain. It wasn't until 1971, however, with the publication of Animals, Men and Morals, a collection of essays edited by Stanley and Roslind Godlovitch and John Harris, that the movement had a manifesto. Richard D. Ryder, in his seminal Victims of Science published in 1975, used the term "speciesism" to refer to discrimination against other species and criticized experiments on animals which were not intended to benefit the individual animal serving as subject of the experiment. By 1975, Peter Singer's Animal Liberation had argued that all animals are equal, and Tom Regan's "The Moral Basis of Vegetarianism" had developed a theory of moral rights for animals. Since 1975, there has been an avalanche of animal rights literature, not only in philosophy but also in the life sciences, medicine, law, education, religion, the social sciences, literature, and other fields. On the subject of the moral status of animals, it is possible that more has been written during the past eighteen years than in all years prior.
The expression "animal rights" is fundamentally an ethical concept; consequently the issue of animal rights is essentially a philosophical issue. It is impossible, in a paragraph, to give a precise statement of the animal rights position. However, it is helpful to isolate several important themes recurrent in the animal rights literature:

(1) The lives of animals - human and nonhuman - have significant value.

(2) Animals - nonhuman and human - have sentience (the capacity to enjoy and suffer, to experience pleasure and pain), desires, and interests.

(3) To obstruct an animal - human or nonhuman - in the pursuit of its interests is to harm that animal. To cause pain or distress or suffering or misery or terror in an animal, unless to benefit that animal, is to harm that animal. To mutilate an animal, unless to benefit that animal, is to harm that animal.

(4) We have a duty not to harm animals nonhuman and human.

(5) Animals - human and nonhuman - have a right not to be harmed by us.

Each of these categorical statements is subject to interpretation. Some animal rightists may not maintain all five or may vary the emphases among the five. These statements are suggested as a "litmus test" to determine the meaning and strength of any animal rights view under consideration.

The Keyguide to Information Sources in Animal Rights will be published in February, 1989. Finally I can retire. Unless, of course, some publisher should happen to express an interest in a work on Henry Salt or Albert Schweitzer or Lewis Gompertz or Thomas Tryon or ]. Howard Moore or human slavery and animal slavery or...

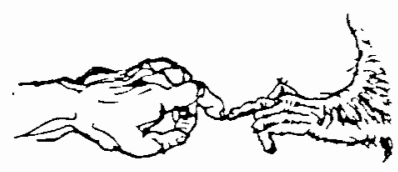

